\title{
Rapidly enlarging acquired capillary hemangioma of the eyelid
}

\author{
Amar Pujari, Mandeep S Bajaj, Shabeer Basheer, Karthika Bhaskaran
}

Dr Rajendra Prasad Centre for Ophthalmic Science, All India Institute of Medical Sciences, New Delhi, India

\section{Correspondence to}

Dr Amar Pujari,

dramarpujari@gmail.com

Accepted 29 March 2017

\section{DESCRIPTION}

\section{Case description}

Case 1: A 10-year-old female presented with a 2 -week history of a small reddish mass on her right upper eyelid. Her past history was otherwise uneventful. Ocular examination and visual acuity were both normal. The right upper eyelid showed a small reddish mass measuring about $2 \times 2 \mathrm{~mm}$ approximately $1 \mathrm{~mm}$ from the eyelashes and at the junction of the medial two thirds and lateral one third of the eyelid (figure 1, top panel). The patient was kept under observation as the mass was small, but it rapidly increased in size over the next 2 weeks (figure 1, middle panel). Complete surgical excision was performed after the stalk was clamped and the bleeding blood vessel at the base was cauterised, followed by closure of the skin with 6-0 silk. A cosmetically acceptable result was achieved after 2 weeks (figure 1, bottom panel).

Case 2: A 35-year-old man presented with a 4-week history of a rapidly enlarging pink to red coloured swelling on his right upper eyelid (figure 2, top panel). Ocular examination of both eyes was normal. However, the right upper eyelid showed a well-defined red swelling measuring around $10 \times 10 \mathrm{~mm}$ with blackish discolouration at the tip due to necrosis. The patient underwent complete surgical excision after the stalk was clamped and
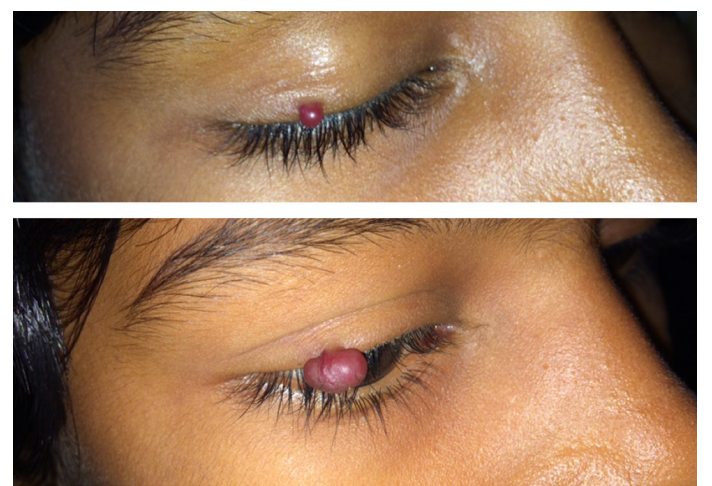

CrossMark

To cite: Pujari A, Bajaj MS, Basheer S, et al. BMJ Case Rep Published Online First: [please include Day Month Year]. doi:10.1136/bcr-2017219777

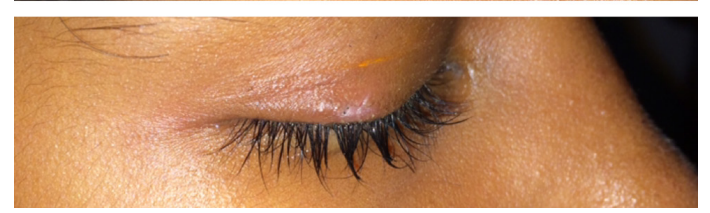

Figure 1 (Top panel) Small reddish mass on the right upper eyelid. (Middle panel) The same mass enlarged over a period of 2 weeks. (Bottom panel) Following complete surgical excision.

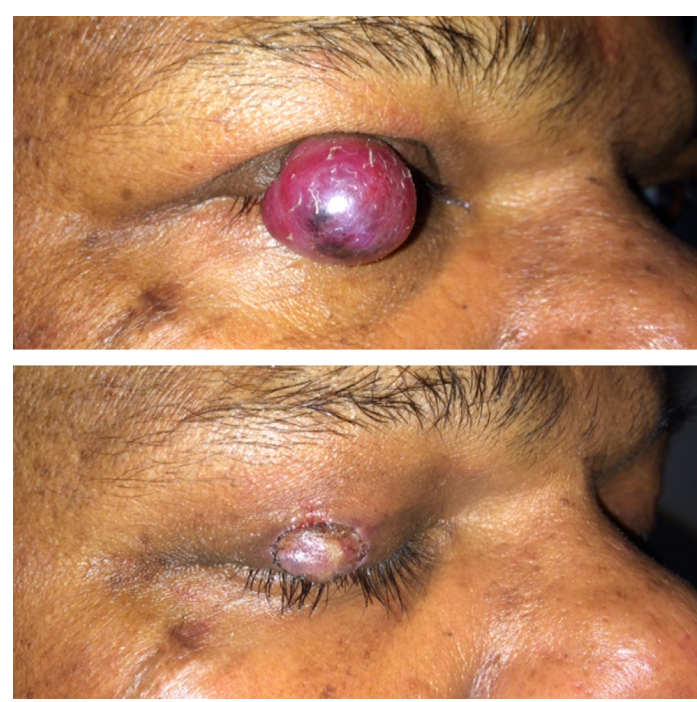

Figure 2 (Top panel) Rapidly enlarging pinkish mass on the right eyelid. (Bottom panel) Following complete surgical excision with skin grafting.

the base was cauterised. Because it was a large defect and to avoid ectropion, a full thickness skin graft was harvested from the post-auricular area (figure 2, bottom panel).

\section{DISCUSSION}

Acquired capillary hemangioma of the eyelid is a relatively uncommon condition. Cases occur around puberty and during pregnancy, probably due to hormonal changes, and also in middleaged men. ${ }^{12}$ Interestingly, we noticed that our two patients presented with a rapidly enlarging pink to red mass on the right upper eyelid at the junction of the medial two thirds and lateral one third. The second case also showed necrosis at the tip of the lesion. The lesions were pedunculated, making

\section{Learning points}

- Acquired capillary hemangiomas of the eyelid were rapidly enlarging in these two patients and so were managed by complete surgical excision.

- Both lesions were pedunculated with a small stalk at the junction of the medial two thirds and lateral third of the eyelid. 
it easy to clamp the stump followed by complete excision and cauterisation of the base.

Contributors $A P, S B, M S B$ together have seen the case and operated successfully. $A P, K B$ and $S B$ have analysed the educational value and wrote the article.

Competing interests None declared.

Patient consent Obtained.

Provenance and peer review Not commissioned; externally peer reviewed.
(C) BMJ Publishing Group Ltd (unless otherwise stated in the text of the article) 2017. All rights reserved. No commercial use is permitted unless otherwise expressly granted.

\section{REFERENCES}

1. Kivanc $S A$, Olcaysu 00 , Gelincik I. Acquired capillary hemangioma of the eyelid in a 49-year-old woman from Turkey. Indian J Ophthalmol 2014;62:969-70.

2. Garg R, Gupta N, Sharma A, et al. Acquired capillary hemangioma of the eyelid in a child. J Pediatr Ophthalmol Strabismus 2009;46:118-9.

Copyright 2017 BMJ Publishing Group. All rights reserved. For permission to reuse any of this content visit

http://group.bmj.com/group/rights-licensing/permissions.

BMJ Case Report Fellows may re-use this article for personal use and teaching without any further permission.

Become a Fellow of BMJ Case Reports today and you can:

- Submit as many cases as you like

- Enjoy fast sympathetic peer review and rapid publication of accepted articles

- Access all the published articles

- Re-use any of the published material for personal use and teaching without further permission

For information on Institutional Fellowships contact consortiasales@bmjgroup.com

Visit casereports.bmj.com for more articles like this and to become a Fellow 